\title{
The Value of Being Innovative in Information Technology
}

\author{
Rodrigo Fernandes Malaquias ${ }^{1,2}{ }^{*}$; Alberto Luiz Albertin ${ }^{1}$
}

\begin{abstract}
We developed this paper in order to better understand the effects of being innovative in the use of Information Technology (IT). Through a measure for listed companies that are innovative in IT use, we developed a quantitative analysis considering the investments made by institutional investors in these companies. As institutional investors, the sample includes observations from 2,880 mutual funds, since managers of these funds are presumed to be experts in choosing good companies to invest financial resources. Regarding the companies' stocks, the final sample of this study is comprised of 592 observations during the period from 2013 to 2015. The main result obtained in this paper indicates that "innovative companies in IT use" receive more investments from institutional investors when compared with the other firms. These results are robust to other variables presented by academic literature as relevant factors to understand resources allocation in financial market.
\end{abstract}

Keywords: IT investments; Latin America; Stock Market; Strategy; Brazil.

Submitted: January $23^{\text {rd }}, 2017$ / Approved: April 16 $6^{\text {th }}, 2018$

\section{Introduction}

Considering the resource based theory (Barney, 1991; Barney et al., 2011), we can state that firms must seek for competitive advantages to reach better results and outperform their competitors. The adequate use of tangible and intangible assets of the firms can create competitive advantage (Barney et al., 2011). In this regard, IT investments have an important role for companies' performance (Bharadwaj, 2000), especially when firms foresee, explore and keep relationship infrastructure and organizational learning (Bhatt \& Grover, 2005). It is important to note, however, that just becoming a successful firm in the present does not guarantee that this success will be sustainable in the future (Su \& Linderman, 2016). Thus, just invest in IT seems to be not enough to achieve better performance, but being innovative in IT use will represent a competitive advantage. "Executives have been always interested in R\&D's contribution to the firm's competitive advantage" (Chiesa et al., 2009, p. 26).

According to Spelta and Albertin (2012, p. 49), "large firms are dependent on IT (to a greater or lesser degree, depending on the industry), both for everyday operations and for the implementation of their business strategies". Considering that some large firms can use IT resources better than their counterparts, what is the value of this differential use of IT? At least, the response for this question can be given in two ways: first, in the company's managerial point of view; secondly, in the point of view from external stakeholders and shareholders. This paper focuses on the value of IT use for shareholders that do not participate directly in the management activities of the firms in which they invest.

Due the relevance of IT investments to the future performance of the firms, investors of listed companies should react to information about new investments. These new investments can positively affect companies' performance and may generate positive outcomes through dividends and capital gains. The value of IT use, in this scenario, was already explored by previous research. For example, Mahmood and Mann (1993) did not find a bivariate strong relationship between IT investment and organizational performance measures, but the authors proposed a theoretical framework that considers implications for market value of the firms due IT investments. Sircar et al. (2000) also included in their quantitative model a variable to represent the stock market, namely the average daily stock closing price.

In the stock market, there are different kinds of investors, such as small individual investors, large individual investors, foreign investors, institutional investors, among others. Despite all these investors are interested in positive gains with their active management, institutional investors are presumed to be better informed and experienced to act in this market and obtain positive returns. Considering the relevance of these investors to the stock market of a given economy, we found a gap in the literature about their reaction to the innovative use of IT by listed firms. Based on this context, the aim of this paper is to analyze the extra amount of financial resources invested by mutual funds (as institutional investors) in companies that are innovative in IT use. To do so, our sample is comprised of listed companies, since all information about their characteristics are public available.

We develop our empirical analysis using data from Brazil, an emerging economy with relevant participation in Latin America. In this market, the speed in which the price of shares reacts to new information disclosed by companies tends to be lower than it is in other developed countries, such as the United States of America. Thus, it is important to analyze some characteristics of companies that institutional investors rely on to make their investment decisions. This relevant information, in the case of this paper, is the innovative use of IT. Moreover, there are inequalities in the access of basic

(1) Fundação Getulio Vargas, Escola de Administração de Empresas de São Paulo (FGV-EAESP), Brazil.

(2) Universidade Federal de Uberlândia, Faculdade de Gestão e Negócios (UFU-FAGEN), Brazil.

*Corresponding author: rodrigofmalaquias@gmail.com 
resources related to information technology in the region of Latin America (Malaquias \& Albertin, 2018), which contributes to the relevance of analyzing the innovative use of IT in a country of the region.

The results found in this research are relevant for Brazil and for other emerging economies, especially for those with the same level of market efficiency (Fama, 1970; 1991). We show that innovative use of IT is perceived by investors as a good sign regarding listed companies. An innovative behavior is a relevant factor for contemporary organizations (Omri, 2015); therefore, institutional investors seem to be willing to buy and keep shares of companies that are innovative in IT use to obtain better performance. Considering that "research on firm resources and capabilities has attracted increasing interest in the past several years" (Helfat, 2000, p. 955), and the increasing of attention to understand the relationship between IT capabilities and firm performance (Santhanam \& Hartono, 2003), the evidence reported in this paper can expand and contribute with the studies about IT capabilities and its potential consequents.

\section{Theoretical Model}

Grounded on the resource based theory (Barney, 1991; Barney et al., 2011), firms must to outperform their competitors using alternatives which are difficult to replicate by them. IT helps firms in this process, but it is also important to highlight that "adopting a resource-based perspective of IT, researchers have argued that since investments in IT are easily duplicated by competitors, investments per se do not provide any sustained advantages" (Bharadwaj, 2000, p. 170). The resources associated with IT involve the following items (and the interaction between them): IT infrastructure, IT business experience, human IT resources, and IT-enabled intangible resources (Bharadwaj, 2000; Bhatt \& Grover, 2005).

"A particular IT capability cannot on its own produce work efficiencies, cost savings, and sales growth because people in the organization ultimately determine the design and use of that system to achieve collective ends" (Nakata et al., 2008, p. 486). Therefore, IT, per se, does not necessarily represents a capability; but managing IT adequately can represent a capability (Bhatt \& Grover, 2005) and create competitive advantage.

Investments in information technology improve organizational efficiency and competitiveness (Kohli \& Devaraj, 2003) and deliver strategic impacts (Tallon et al., 2000); IT investments can also improve the performance of partnerships of collaborative works (Chang et al., 2015) and support the development of supply chain agility (Liu et al., 2013). "A flexible IT infrastructure also leads to a high level of supply chain agility. First, the connectivity of IT components helps the firm consolidate information flow with channel partners using an integrated technological interface" (Liu et al., 2013, p. 1455). Nakata et al. (2008) state that IT capability contributes to firms' performance, but this path is not necessarily direct, and the arguments previously presented indicates some contributions that firms can obtain from adequate investments in IT. Considering that innovative behavior has a positive effect on business performance (Omri, 2015) and that product innovations are also important to improve performance (Löfsten, 2014), our arguments indicate that an innovative use of IT creates value for firms. Figure 1 summarizes the research hypothesis of this paper:

H1: institutional investors positively evaluate companies that present an innovative IT use.

Figure 1: Research model. Notes: Innovative IT use $=$ represents firms that are innovative in IT use; Financial Resources Invested in Firms = the amount of financial resources invested in listed companies by institutional investors.

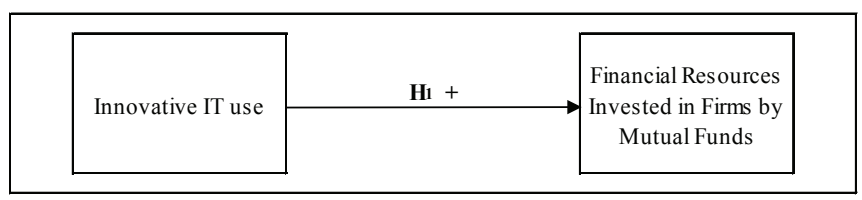

In the financial market, there are different types of actors taking investment decisions, such as individual investors, institutional investors, foreign investors, among others. We chose to analyze in this paper the potential effects of being an innovative company (in the use of IT) on the decisions taken by mutual funds, when they choose firms to allocate their financial resources. Our analysis can indicate another factor that should be relevant to be considered in quantitative models that address the financial market, as well as indicate the perception regarding IT benefits for institutional investors (mutual funds, in the case of this study), which are specialized in stock selection.

The body of literature that explores the behavior of the stock market is large and considerable. Fama and French (1993) identified three relevant risk factors in the returns of stocks, which are: an overall market factor, a factor related with size and a factor related with book-tomarket equity. Recently, Fama and French (2015) observed that a fivefactor model can explain better the variations in stocks, when compared with the three-factor model. The additional factors are related with profitability and investment patterns of the companies. The momentum factor presented by Carhart (1997) is also usually combined with the Fama and French (1993) factors to analyze the performance of stocks/funds in the financial market. In this paper, we explore an additional factor that can be used to understand the behavior of the stock market and the reaction of investors to innovative investments made in IT. Nevertheless, we consider the previous factors indicated by literature as control variables, in order to analyze the robustness of this new factor (being innovative in IT).

\section{Method}

The first step to develop this research was to identify the portfolio composition of Brazilian mutual funds. We selected this information from Economatica database. "The Economatica System is used by thousands of analysts following Latin America's stock markets, government bonds, the fund industry and various indicators" (Economatica, 2016). We found 2,880 different investment funds (mutual funds) with available information to develop this research (considering the years of 2013, 2014 and 2015, as we will explain in the following paragraphs). 
The dependent variable of this research is the amount of resources that all mutual funds have invested in each listed firm at the end of each year of analysis. In Equation 1 we highlight how we calculate this variable.

$$
\operatorname{Res}_{\mathrm{j} \mathrm{t}}=\sum_{i=1}^{n}\left(\operatorname{Res}_{\mathrm{ij} \mathrm{t}}\right)
$$

Where: Res i j $\mathrm{t}=$ the amount of financial resources (\%) that the fund $i$ has invested in firm $j$ at the end of year $t$; Res $j t=$ the amount of financial resources $(\%)$ that all funds (from $i=1$ to $i=n$ ) have invested in firm $j$ at the end of year $t$.

In order to avoid scalar problems in the quantitative tests, we also calculated the natural logarithm of the variable "Res". Therefore, for the purpose of robustness check, we also generate the variable Res(ln), as we present in Equation 2.

$$
\operatorname{Res}(\ln )_{j \mathrm{t}}=\ln \left(1+\operatorname{Res}_{\mathrm{j} t}\right)
$$

Where: Res $\mathrm{j} t=$ the amount of financial resources (\%) that all funds (from $\mathrm{i}=1$ to $\mathrm{i}=\mathrm{n}$ ) have invested in firm $\mathrm{j}$ at the end of year $\mathrm{t}$; Res(ln) $j t=$ the natural logarithm of the variable "Res". We add " 1 " because there are some observations in which the total of financial resources is zero.

Then, we selected all listed Brazilian companies available in the portfolio of the investment funds. We used Equations 1 and 2 to estimate the percentage of aggregate portfolios invested in each firm, each end of year (2013, 2014 and 2015). This information was recorded in an electronic spreadsheet.

The second stage was the selection of Brazilian listed firms with available information to calculate the factors that academic literature indicate as relevant to understand the behavior of stock market (Fama \& French, 1993; 2015; Carhart, 1997). We excluded of the sample companies with the absence of value for one of these variables, and we also excluded companies of the finance sector, because the operations of this industry are usually different of the other companies. Therefore, based on previous literature (Fama \& French, 1993; 2015; Carhart, 1997), year by year, we create (the breakpoint is the median):

i) a group of small and a group of big firms, based on their market values;

ii) a group of firms with low liquidity in the stock market and a group of firms with high liquidity (in Brazil, the main stock index, called Ibovespa, is composed by the most liquid firms, and this index is usually adopted as a measure for the Brazilian capital market);

iii) a group of firms with low Book Equity / Market Equity (BEME) ratio, and a group of firms with high BEME ratio; iv) a group of firms with low average past returns of stocks and a group of firms with high average past returns of their respective stocks;

v) a group of firms with low investment levels (which is the difference of total net assets of the year $t+1$ minus the total net assets of year $t$, divided by the total net assets of year $\mathrm{t}$ ) and a group of firms with high investment levels. It is important to note that these investments were not necessarily made on IT; they are general investments in assets made by companies;

vi) a group of firms with low profitability indexes and a group of firms with high indexes of profitability.

These groups were create to check the robustness of the quantitative analysis of $\mathrm{H} 1$, since these factors are already available in current literature as important risk factors to understand the behavior of stock market.

After creating all these groups, we had the information of the company's name and its respective group, each year. We combined this information with the first database created in the first step of this study. Therefore, our database contains information of the company's name, its respective group and the amount received by institutional investors.

Finally, we have selected a list of innovative companies in IT. We obtained this list considering the ranking of the 100+ innovative in IT Use (IT Forum, 2013; 2014; 2015). “The 100+ Innovative in IT Use award, conducted in partnership with $\mathrm{PwC}$, contextualizes innovation governed by the largest companies in Brazil by combining process versus practice in the use of technology for the benefit of business innovation" (IT Forum, 2016). In our database, we created a dummy variable, where a given company in a given year receives 1 if it is ranked in the list of $100+$ innovative in IT, and 0 otherwise.

\section{Results}

We elaborate Table 1 to report some characteristics of the sample, specifically regarding the amount invested in each company of the sample by institutional investors (mutual funds) and the number of companies that received score 1 in the dummy variable of $100+$ Innovative in IT use. There are companies in the sample that receive a great attention from mutual funds, because the aggregate amount of portfolio holdings allocation that they have received is high. The average amount is $263.9 \%$; on the other hand, there are some firms that did not receive any allocation from institutional investors during this period, as Table 1 also indicates.

Table 1: Descriptive statistics of data. Notes: Inv(IT) $=$ dummy variable, which receives 1 if the firm in the year $t$ is listed in the $100+$ innovative firms in the use of Information Technology; Res = the amount of financial resources that all funds have invested in firm $\mathrm{j}$ at the end of year $\mathrm{t}$; $\operatorname{Res}(\ln )=$ natural logarithm of the variable "Res".

\begin{tabular}{lccccc}
\hline Variable & $\mathbf{n}$ & mean & s.d. & min. & max. \\
\hline Inv(IT) & 592 & 0.081 & 0.273 & 0.000 & 1.000 \\
$\operatorname{Res}$ & 592 & 263.979 & 619.870 & 0.000 & $5,141.356$ \\
$\operatorname{Res}(\ln )$ & 592 & 3.986 & 2.129 & 0.000 & 8.545 \\
\hline
\end{tabular}


The other variable created to represent the amount of financial resources invested in each company has a low variation in comparison with the original measure (low standard deviation compared to the mean). Our sample study contains 592 observations from companies during the period from 2013 to 2015, and, as we commented before, there are some cases with high amount of investments, but others received zero. In order to explore these allocations with more details, we segregate the database considering companies ranked in the list of the "100+ Innovative in IT use" and companies that are not in this list. Table 2 contains the results and the hypothesis test. Table 3 contains equivalent information, but the dependent variable is the natural logarithmic of the total amount invested in each company, as we explained in the methodology section.

The information reported both in Tables 2 and 3 indicate that companies listed at the $100+$ Innovative in IT use $[\operatorname{Inv}(\mathrm{IT})=1]$ received more portfolio allocations from institutional investors. According to Table 2 , this amount is more than the quadruple of the amount invested in the other firms. These evidences indicate that $\mathrm{H} 1$ is supported. Therefore, it is an indicative that institutional investors, who are presumed to be informed participants in the financial market, give attention to innovative firms in the use of IT.

Table 2: The effect of IT use on the amount of financial resources invested in firms - dependent variable: Res. Notes: Inv(IT) = dummy variable, which receives 1 if the firm in the year $t$ is listed in the 100+ innovative firms in the use of Information Technology; Res = the amount of financial resources that all funds have invested in firm $j$ at the end of year $t$; $\operatorname{Res}(\ln )=$ natural logarithm of the variable "Res".

\begin{tabular}{lccccc}
\hline Variable & n & mean & s.e. & t & sig. \\
\hline $\operatorname{Inv}(\mathrm{IT})=0$ & 544 & 200.970 & 18.208 & & \\
$\operatorname{Inv}(\mathrm{IT})=1$ & 48 & 978.071 & 213.174 & & 0.000 \\
\hline
\end{tabular}

Table 3: The effect of IT use on the amount of financial resources invested in firms - dependent variable: Res(ln). Notes: $\operatorname{Inv}(\mathrm{IT})=$ dummy variable, which receives 1 if the firm in the year $t$ is listed in the 100+ innovative firms in the use of Information Technology; Res = the amount of financial resources that all funds have invested in firm $j$ at the end of year $t$; $\operatorname{Res}(\ln )=$ natural logarithm of the variable "Res".

\begin{tabular}{lccccc}
\hline Variable & n & mean & s.e. & t & sig. \\
\hline $\operatorname{Inv}(\mathrm{IT})=0$ & 544 & 3.909 & 0.087 & & \\
$\operatorname{Inv}(\mathrm{IT})=1$ & 48 & 4.865 & 0.412 & -3.005 & 0.003 \\
\hline
\end{tabular}

To test the robustness of the results obtained in this paper, we considered the relevant factors also presented by financial literature that can affect the resources allocations of institutional investors in financial market (Fama \& French, 1993; Carhart, 1997; Fama \& French, 2015). As we explained in the method section, the factors we used in these robustness checks were: the size of listed firms; the difference between book equity value and market value; the profitability of firms; the past stock returns of the firm; the investments level. We also analyzed the liquidity of the firms. These results are available in Appendices from A to $\mathrm{F}$.
According these additional analyses, we observed that being a company with innovative use in IT represents a relevant characteristic not only to be available in the portfolio composition of institutional investors, but also these companies receive higher percentage of investments from these investors. For example, according to Appendix $\mathrm{C}$, for a subset of companies with higher difference between book equity and market equity (High BEME), innovative firms receive a large amount of resources (1,391.2, on average) when compared with the other firms (145.6, on average); on the other hand, in the subset with lower difference between book equity and market equity (Low BEME), innovative firms also receive higher amounts of resources (528.9, on average) than the other firms (255.8, on average). In this way, even considering previous factors presented as relevant by academic literature, the characteristic of being an innovative company in the IT use represents a relevant information to institutional investors.

\section{Final Remarks}

Information Technology contributes with the value added by firms, especially through the combination of internal resources and their adequate management as a valuable resource. Considering the resource based theory (Barney, 1991; Barney et al., 2011), firms should use IT capabilities to achieve competitive advantage with resources that are difficult to imitate. The effects of IT capabilities on firm's performance are not necessarily direct (Nakata et al., 2008), but the information regarding some companies which are innovative in IT use can indicate that those firms present better chances of being successful firms to make financial investments. We developed this paper considering this context, and we have analyzed the value of being innovative for a specific kind of investors: mutual funds, institutional investors with specialized knowledge in stock selection.

The study sample comprises 592 observations from listed firms, during the years from 2013 to 2015 . The dependent variable is the percentage of mutual funds' portfolios invested in each firm, and the sample includes portfolio data of 2,880 Brazilian mutual funds. We observe with the analysis of this paper that the information regarding being an innovative firm in the use of IT seems to be a relevant factor for institutional investors to take decisions regarding portfolio allocation. The dichotomous of the main independent variable (being innovative in IT use) has some limitation; nevertheless, it is important to highlight that this simple measurement of being an innovative firm has a significant effect on the financial market. Furthermore, this result is robust when compared with previous factors already studied by academic literature on stock market. Information on other kind of assets (such intangible assets) are also relevant to explain the attractiveness of stocks, but this information should already been captured by the other factors previously studied, specifically the factor investments levels (Fama \& French, 2015; tests in Appendix E). Even considering these factors, the results of the dichotomous variable were statistically significant in this paper.

Other studies already have evaluated the value of IT, for example, considering executive's perception, and found a positive effect of IT spending on business goals (Tallon et al., 2000), and the value of IT 
to firm's market value (Mahmood \& Mann, 1993; Sircar et al., 2000). This paper confirms the relevance of IT investments, reinforces the positive effects that these investments have on investors' perception, and expands previous research using a new avenue to analyze the relationship between IT and the value of these investments. Managers need to manage the complexities related with product innovation, as well as they need to pay attention to the relationship between product innovation and business performance (Löfsten, 2014). The results of this paper indicate that this management is expected to present a positive effect on performance forecasting from institutional investors.

Additionally, the results of this paper have implications for the strategy literature, since IT investments are related with capabilities and strategic planning. Firms committed with long term goals and that have care to align their internal resources and create competitive advantages tend to overcome their competitors. The strategic use of IT has a positive effect in this regard; when some firms present an innovative way of IT use, it can represent a good sign to the financial market about the potential benefits (and positive results) of this choice, made by companies' managers. Our paper indicates strong evidences that corroborates with this reasoning.

The main limitation of this paper is the consideration of only listed companies with data available for all variables included in the quantitative models, such as the size of the firms, their BEME indexes, their past stock returns and the proxies for new investments and profitability. Despite the inclusion of these variables represent a limitation of the database, in terms of the number of firms with complete information, these variables allow us to evaluate the robustness of the results considering some important factors previously studied by academic literature. Another limitation is the consideration of the portfolio composition of mutual funds, since there are other institutional investors that also operates in the Brazilian financial market (such as the multimarket funds). This limitation indicates some opportunities for new studies, for example, comparing the value of being innovative among different types of institutional investors that operates in the same emerging economy.

\section{About authors}

Rodrigo Fernandes Malaquias: He is a Full Time Professor at Universidade Federal de Uberlândia (UFU), Brazil. In 2012, he received his $\mathrm{PhD}$ in Business Administration from FGV-EAESP, Brazil. In 2015, he was a Visiting Research Scholar at DePaul University in Chicago, USA, where he developed his first post-doc research. During 2016/2017, he also developed post-doc research at FGV-EAESP. His papers have been published or accepted for publication by peerreviewed journals, including Research in International Business and Finance, Computers in Human Behavior, Accounting \& Finance Review (USP), Information Development, Information Technology for Development, International Journal of Business Information Systems, Technology and Disability, Brazilian Review of Finance, Brazilian Business Review, Journal of Operations and Supply Chain Management, TOJDE, among others.
Alberto Luiz Albertin: Professor Albertin received his MSc and a $\mathrm{PhD}$ in Business Administration from Faculdade de Economia, Administração e Contabilidade da Universidade de São Paulo (FEA-USP). He is a Full Time Professor at Escola de Administração de Empresas de São Paulo da Fundação Getulio Vargas (FGV-EAESP) and Coordinator of the Center for Applied Information Technology (CIA), of the Program for Excellence in Business in Digital Age (NED) and of the Information Technology research area of professional post graduation programs at FGV-EAESP. He is also a consultant in Administration of Information Technology, Business in Digital Age and Project Management. Previously, he has worked for several years in national and multinational companies in the IT area. He also wrote various studies, researches and articles about information technology and has won many prizes for his works.

\section{References}

Barney, J. (1991). Firm Resources and Sustained Competitive Advantage. Journal of Management, 17(1), 99-120. doi: $10.1177 / 014920639101700108$

Barney, J. B., Ketchen Jr., D. J., \& Wright, M. (2011). The Future of Resource-Based Theory: Revitalization or Decline? Journal of Management, 37(5), 1299-1315. doi: 10.1177/0149206310391805

Bharadwaj, A. S. (2000). A Resource-Based Perspective on Information Technology Capability and Firm Performance: An Empirical Investigation. MIS Quarterly, 24(1), 169-196. doi: 10.2307/3250983

Bhatt, G. D., \& Grover, V. (2005). Types of Information Technology Capabilities and Their Role in Competitive Advantage: An Empirical Study. Journal of Management Information Systems, 22(2), 253-277. doi: 10.1080/07421222.2005.11045844

Carhart, M. M. (1997). On Persistence in Mutual Fund Performance. The Journal of Finance, 52(1), 57-82. doi: 10.2307/2329556

Chang, K.-H., Chen, Y.-r., \& Huang, H.-F. (2015). Information technology and partnership dynamic capabilities in international subcontracting relationships. International Business Review, 24(2), 276-286. doi: 10.1016/j.ibusrev.2014.08.003

Chiesa, V., Frattini, F., Lazzarotti, V., \& Manzini, R. (2009). Performance measurement of research and development activities. European Journal of Innovation Management, 12(1), 25-61. doi: $10.1108 / 14601060910928166$

Economatica (2016). Home / Leader in systems for investment analysis. Available at: https://economatica.com

Fama, E. F. (1970). Efficient Capital Markets: A Review of Theory and Empirical Work. The Journal of Finance, 25(2), 383-417. doi: $10.2307 / 2325486$

Fama, E. F. (1991). Efficient Capital Markets: II. The Journal of Finance, 46(5), 1575-1617. doi: 10.2307/2328565 
Fama, E. F., \& French, K. R. (1993). Common risk factors in the returns on stock and bonds. Journal of Financial Economics, 33(1), 3-56. doi: 10.1016/0304-405X(93)90023-5

Fama, E. F., \& French, K. R. (2015). A five-factor asset pricing model. Journal of Financial Economics, 116(1), 1-22. doi: 10.1016/j.jfineco.2014.10.010

Helfat, C. E. (2000). Guest Editor's Introduction to the Special Issue: The Evolution of Firm Capabilities. Strategic Management Journal, 21(10/11), 955-959.

IT Forum (2016). 100+ Inovadoras no uso de TI [100+ Innovative Firms in IT use]. Available at: http://itforum365.com.br

IT Forum. (2013). Ranking 100+ Inovadoras no uso de TI [Ranking of the 100+ Innovative Firms in IT use]. 13ª Ed. Revista IT Forum.

IT Forum. (2014). Ranking 100+ Inovadoras no uso de TI [Ranking of the 100+ Innovative Firms in IT use]. 14 a Ed. Revista IT Forum.

IT Forum. (2015). Ranking 100+ Inovadoras no uso de TI [Ranking of the 100+ Innovative Firms in IT use]. 15ª Ed. Revista IT Forum.

Kohli, R., \& Devaraj, S. (2003). Measuring Information Technology Payoff: A Meta-Analysis of Structural Variables in Firm-Level Empirical Research. Information Systems Research, 14(2), 127-145. doi: 10.1287/isre.14.2.127.16019

Liu, H., Ke, W., Wei, K. K., \& Hua, Z. (2013). The impact of IT capabilities on firm performance: The mediating roles of absorptive capacity and supply chain agility. Decision Support Systems, 54(3), 1452-1462. doi: 10.1016/j.dss.2012.12.016

Löfsten, H. (2014). Production innovation processes and the trade-off between product innovation performance and business performance. European Journal of Innovation Management, 17(1), 61-84. doi: 10.1108/EJIM-04-2013-0034
Mahmood, M. A., \& Mann, G. J. (1993). Measuring the organizational impact of information technology investment: an exploratory study. Journal of Management Information Systems, 10(1), 97-122. doi: 10.1080/07421222.1993.11517992

Malaquias, R. F., \& Albertin, A. L. (2018). Challenges for development and technological advancement: an analysis of Latin America. Information Development, on-line first. doi: 10.1177/0266666918756170

Nakata, C., Zhu, Z., Kraimer, M. L. (2008). The Complex Contribution of Information Technology Capability to Business Performance. Journal of Managerial Issues, 20(4), 485-506.

Omri, W. (2015). Innovative behavior and venture performance of SMEs: The moderating effect of environmental dynamism. European Journal of Innovation Management, 18(2), 195-217. doi: 10.1108/EJIM-02-2013-0015

Santhanam, R., \& Hartono, E. (2003). Issues in Linking Information Technology Capability to Firm Performance. MIS Quarterly, 27(1), 125-153. doi: 10.2307/30036521

Sircar, S., Turnbow, J. L., \& Bordoloi, B. (2000). A Framework for Assessing the Relationship between Information Technology Investments and Firm Performance. Journal of Management Information Systems, 16(4), 69-97. doi: 10.1080/07421222.2000.11518266

Spelta, A. G., \& Albertin, A. L. (2012). Project Management Offices in the IT Area: a context-discriminant model for their establishment. Information Systems Management, 29(1), 40-54. doi: $10.1080 / 10580530.2012 .634296$

Su, H.-C., \& Linderman, K. (2016). An Empirical Investigation in Sustaining High-Quality Performance. Decision Sciences, 47(5), 787 819. doi: $10.1111 /$ deci.12210

Tallon, P. P., Kraemer, K. L., \& Gurbaxani, V. (2000). Executives' Perceptions of the Business Value of Information Technology: A ProcessOriented Approach. Journal of Management Information Systems, 16(4), 145-173. doi: 10.1080/07421222.2000.11518269 


\section{Appendices List}

\section{Appendix A:}

The effect of IT use on the amount of financial resources invested in firms, by Size

\begin{tabular}{llccccc}
\hline Group & Variable & $\mathbf{n}$ & mean & s.e. & t & sig. \\
\hline \multirow{2}{*}{ Small } & $\operatorname{Inv}(\mathrm{IT})=0$ & 290 & 78.466 & 6.599 & & \\
& $\operatorname{Inv}(\mathrm{IT})=1$ & 6 & 3.085 & 1.955 & & 0.102 \\
\hline \multirow{2}{*}{ Big } & $\operatorname{Inv}(\mathrm{IT})=0$ & 254 & 340.837 & 36.360 & & \\
& $\operatorname{Inv}(\mathrm{IT})=1$ & 42 & $1,117.354$ & 236.115 & -5.942 & 0.000 \\
\hline
\end{tabular}

Notes: Small $=50 \%$ of the companies in the sample with the smallest market values; $\mathrm{Big}=50 \%$ of the companies in the sample with the highest market values; Inv(IT) = dummy variable, which receives 1 if the firm in the year $\mathrm{t}$ is listed in the $100+$ innovative firms in the use of Information Technology; dependent variable: Res = the amount of financial resources that all funds have invested in firm $j$ at the end of year $\mathrm{t}$.

\section{Appendix B:}

The effect of IT use on the amount of financial resources invested in firms, by liquidity level

\begin{tabular}{llccccc}
\hline Group & Variable & $\mathbf{n}$ & mean & s.e. & t & sig. \\
\hline \multirow{2}{*}{ Low Liq. } & $\operatorname{Inv}(\mathrm{IT})=0$ & 284 & 57.154 & 4.841 & & \\
& $\operatorname{Inv}(\mathrm{IT})=1$ & 12 & 1.640 & 1.033 & & 0.019 \\
\hline \multirow{2}{*}{ High Liq. } & $\operatorname{Inv}(\mathrm{IT})=0$ & 260 & 358.062 & 35.267 & & \\
& $\operatorname{Inv}(\mathrm{IT})=1$ & 36 & $1,303.548$ & 263.169 & -6.971 & 0.000 \\
\hline
\end{tabular}

Notes: Low Liq. $=50 \%$ of the companies in the sample with the smallest liquidity indexes in the stock market; High Liq. $=50 \%$ of the companies in the sample with the highest liquidity indexes in the stock market; $\operatorname{Inv}(\mathrm{IT})=$ dummy variable, which receives 1 if the firm in the year $\mathrm{t}$ is listed in the $100+$ innovative firms in the use of Information Technology; dependent variable: Res = the amount of financial resources that all funds have invested in firm $j$ at the end of year $t$.

Appendix C:

The effect of IT use on the amount of financial resources invested in firms, by BEME index

\begin{tabular}{llccccc}
\hline Group & Variable & $\mathbf{n}$ & mean & s.e. & t & sig. \\
\hline \multirow{2}{*}{ Low BEME } & $\operatorname{Inv}(\mathrm{IT})=0$ & 273 & 255.852 & 27.587 & & \\
& $\operatorname{Inv}(\mathrm{IT})=1$ & 23 & 528.957 & 152.019 & -2.612 & 0.010 \\
\hline \multirow{2}{*}{ High BEME } & $\operatorname{Inv}(\mathrm{IT})=0$ & 271 & 145.684 & 23.312 & & \\
& $\operatorname{Inv}(\mathrm{IT})=1$ & 25 & $1,391.255$ & 369.503 & -9.263 & 0.000 \\
\hline
\end{tabular}

Notes: Low BEME $=50 \%$ of the companies in the sample with the smallest BEME indexes; High BEME $=50 \%$ of the companies in the sample with the highest BEME indexes; Inv(IT) = dummy variable, which receives 1 if the firm in the year $t$ is listed in the 100+ innovative firms in the use of Information Technology; dependent variable: Res $=$ the amount of financial resources that all funds have invested in firm $j$ at the end of year $t$.
Appendix D:

The effect of IT use on the amount of financial resources invested in firms, by Past Stock Returns

\begin{tabular}{llccccc}
\hline Group & Variable & $\mathbf{n}$ & mean & s.e. & t & sig. \\
\hline \multirow{2}{*}{ Low Ret. } & $\operatorname{Inv}(\mathrm{IT})=0$ & 267 & 222.754 & 29.479 & & \\
& $\operatorname{Inv}(\mathrm{IT})=1$ & 29 & $1,335.398$ & 321.747 & -8.082 & 0.000 \\
\hline \multirow{2}{*}{ High Ret. } & $\operatorname{Inv}(\mathrm{IT})=0$ & 277 & 179.973 & 21.689 & & \\
& $\operatorname{Inv}(\mathrm{IT})=1$ & 19 & 432.677 & 163.177 & -2.722 & 0.007 \\
\hline
\end{tabular}

Notes: Low Ret. $=50 \%$ of the companies in the sample with the smallest past stock returns during the year; High Ret. $=50 \%$ of the companies in the sample with the highest past stock returns during the year; $\operatorname{Inv}(\mathrm{IT})=$ dummy variable, which receives 1 if the firm in the year $\mathrm{t}$ is listed in the 100+ innovative firms in the use of Information Technology; dependent variable: Res = the amount of financial resources that all funds have invested in firm $j$ at the end of year $t$.

Appendix E:

The effect of IT use on the amount of financial resources invested in firms, by Investment levels

\begin{tabular}{llccccc}
\hline Group & Variable & $\mathbf{n}$ & mean & s.e. & t & sig. \\
\hline \multirow{2}{*}{ Low Inv. } & $\operatorname{Inv}(\mathrm{IT})=0$ & 279 & 144.878 & 17.353 & & \\
& $\operatorname{Inv}(\mathrm{IT})=1$ & 17 & 726.735 & 303.454 & -5.740 & 0.000 \\
\hline \multirow{2}{*}{ High Inv. } & $\operatorname{Inv}(\mathrm{IT})=0$ & 265 & 260.026 & 32.252 & & \\
& $\operatorname{Inv}(\mathrm{IT})=1$ & 31 & $1,115.900$ & 285.511 & -6.343 & 0.000 \\
\hline
\end{tabular}

Notes: Low Inv. $=50 \%$ of the companies in the sample with the smallest investment levels; High Inv. $=50 \%$ of the companies in the sample with the highest investment levels; Inv(IT) = dummy variable, which receives 1 if the firm in the year $t$ is listed in the $100+$ innovative firms in the use of Information Technology; dependent variable: Res $=$ the amount of financial resources that all funds have invested in firm $j$ at the end of year $t$.

Appendix F:

The effect of IT use on the amount of financial resources invested in firms, by Profitability

\begin{tabular}{llccccc}
\hline Group & Variable & $\mathbf{n}$ & mean & s.e. & t & sig. \\
\hline \multirow{2}{*}{ Low Profit. } & $\operatorname{Inv}(\mathrm{IT})=0$ & 273 & 154.626 & 23.898 & & \\
& $\operatorname{Inv}(\mathrm{IT})=1$ & 23 & $1,635.198$ & 390.280 & -10.697 & 0.000 \\
\hline \multirow{2}{*}{ High Profit. } & $\operatorname{Inv}(\mathrm{IT})=0$ & 271 & 247.657 & 27.253 & & \\
& $\operatorname{Inv}(\mathrm{IT})=1$ & 25 & 373.514 & 103.100 & -1.325 & 0.186 \\
\hline
\end{tabular}

Notes: Low Profit. $=50 \%$ of the companies in the sample with the smallest profitability indexes; High Profit. $=50 \%$ of the companies in the sample with the highest profitability indexes; $\operatorname{Inv}(\mathrm{IT})=$ dummy variable, which receives 1 if the firm in the year $t$ is listed in the $100+$ innovative firms in the use of Information Technology; dependent variable: Res $=$ the amount of financial resources that all funds have invested in firm $\mathrm{j}$ at the end of year $\mathrm{t}$. 
